\title{
Factories`Observance to the Legal Framework for the Protection of the Environment: A Case Study in Debre Berhan Town
}

\author{
By Petros Fanta Choramo*
}

\begin{abstract}
This study mainly focused on industrial pollution in Debre Berhan town and observance of the legal frameworks concerning industrial pollution. The researcher gives more emphasis to identify the cause and effect of pollution in the town. It is also given due attention to various measures being taken by factories, pertinent government bodies, and the society based on relevant laws and observance of legal frameworks by them, in order to prevent pollution. This study used the primary and secondary source of data. The sampling technique which was selected for the study was purposive sampling. At the end, the research intended to address the extent of pollution and the overall challenges that are impediments which limit the achievement of creating a healthy environment that suits for the life of human being, fauna and flora. Accordingly, some of the final findings of the study are; the extent of pollution in Debre Berhan Town is increasing from time to time, while such pollution is mainly emanated from the fault of concerned government bodies, factories, societies.
\end{abstract}

Keywords: Environment; Factories; Pollution; Pollutants; Legal Framework and Institutional Frameworks.

\section{Introduction}

Today, interaction of human beings with nature is so extensive. The environmental issues have assumed such proportions as to affect all humanity.

Industrialisation, urbanisation, population explosion, overexploitation of resources, depletion of traditional sources of energy, and the search for new ones, the disruption of natural ecological balances as well as the destruction of a multitude of animal and plant species for economic reasons are the major factors that have contributed to environmental deterioration. ${ }^{1}$

Nature provides the most hygienic and health environment for the survival of mankind but this environment has been changed by mankind for selfish ends by adding concrete, charcoal, plastics toxic chemicals, hazardous wastes and many more objects, devices and processes. These manmade additions have unbalanced the ecosystem and are primarily responsible for environmental pollution and consequent health hazards. The industrial revolution had brought enormous comforts to mankind also been responsible for manifold miseries and disadvantages to it. The process of industrialisation, which aimed at mass production of goods of

*LL.B, LL.M, Lecturer at Mizan - Tepi University, Mīzan Teferī, Ethiopia.

E-mail: Fantapetrosa@gmail.com.

${ }^{1}$ Senger (2007) at 2.

https://doi.org/10.30958/aj1.7-4-5

doi=10.30958/aj1.7-4-5 
better quality to fulfill the human needs is also polluting the environment, and now is fast assuming menacing proportions. As elsewhere in the world some cities are afflicted with the problem of environmental pollution resulting from industrialisation in Ethiopia. Indeed, Ethiopian legal system defined "environment" as the totality of all material whether in their natural state or modified or changed by humans, their external spaces and the interactions which affected their quality or quantity and the welfare of human or other living beings including but not restricted to, land atmosphere, weather and climate, water, living things and aesthetics. ${ }^{2}$ Industries are widely being established by the government on various regions of the country. For instance, recently, the industry zone was established at Ambo, Nekemte, Dire Dawa and Jimma in addition to the existing industry zones at kombolcha, Hawassa, Addis Ababa, etc. ${ }^{3}$. Thus, it can be said that industrial development is started to be seen in Ethiopia since various cities of the country are becoming an industry zone by the government. On the other hand, private sector is also engaging in planting factories in Ethiopia and Debre Berhan Town can be an example for such phenomena.

The problem of environmental pollution, which initially started with the advent of man on earth, grew extremely acute in the developed, as well as the developing countries. The third world countries, like Ethiopia, are seeking the transfer of technology without and insurance against the risk or danger of pollution which is posing a grave danger not only for the workers within the premises of the industry, but also for the people in the vicinity. The Debre Berhan Town which is located within Amhara National Regional State in Ethiopia is not an exception to this phenomenon. Recently, the Amhara National Regional state held such town as the second industry zone in the region next to Kombolcha. As a result, the number of industries in Debre Berhan Town is increasing from time to time.

Like another Ethiopian towns, the environmental pollution in general and industrial pollution in particular was common phenomena in Debre Berhan Town. For instance, a river around the town called. 'Beresa' is highly polluted from the emission of wastes by some factories in the town. The communities around the industries were vulnerable to the viral and bacterial disease because of air pollution. Furthermore, currently increasing number of industries in the town has a direct impact on the increment of pollution. However, the cause of such increment and on whose fault that such pollution was increasing was not researched.

\section{Conceptual understandings and Legal and Institutional Frameworks of Environment, its Pollution and Protection}

A legal definition of environment helps delineate the scope of the subject, determine the application of legal rules and the extent of liability when harm occurs. The word environment is derived from an ancient French word "environner"

\footnotetext{
${ }^{2}$ Environmental Pollution Control Proclamation of Federal Democratic Republic of Ethiopia, Proc No.300/2002, Art 2(6).

${ }^{3}$ The late Ethiopian Prime minister, Hailemariam Desalegn's speech via Ethiopian Broadcasting Corporation on May 9, 2007.
} 
meaning to encircle. By broadly applying to surroundings, environment can include the aggregate of natural, social and cultural condition that influence the life of an individual or community. ${ }^{4}$ Geographically environment can refer to include limited areas or encompasses the entire planet including the atmosphere and stratosphere

Of course defining an environment is not an easy task. Most writers, treaties, declarations, codes of conduct guidelines, etc. defined it in different. William, $P C$. $\&$ M. Cunningham defined environment as a circumstance or a condition that surrounds an organism or group of organisms or complex of social or cultural conditions that affect an individual or community. ${ }^{5}$

The word "pollution" is derived from the Latin word "pollutus" which means defiled or to make dirty or to pollute". 6

Industrial Pollution is pollution caused by the pollutants released from industries and never ending problems resulted in to disease epidemics appearing so frequently. When we say types of industrial pollution, there are various kinds of pollutions, namely, air pollution, water pollution, soil pollution, noise pollution, radioactive pollution, thermal pollution, plant pollution and maritime pollution etc. Those types of pollution which are related with industries are discussed below.

\section{Legal Frameworks}

National Laws

i. 1995 FDRE constitution: Even though the constitution provides the general principles, it is not silent on environment protection. It gives the right to all persons to live in health and clear environment. This is clearly envisaged from article 44(1) of FDRE constitution further more article 92 of the same provides obligation on the side of government to ensure that all Ethiopian live in a clean and health environment" (emphasis added). On the other hand people have the right to full consultation and to the expression of views in the planning and implementation of environmental policies and project that affect them directly. ${ }^{7}$ Both government and citizens shall have the duty to protect the environment. This is mainly to protect the environment from damage like pollution.

ii. The Environmental Protection Organs Establishment Proclamation No 295/2002

iii. Environmental Impact Assessment Proclamation No 299/2002

iv. Environmental Pollution Control Proclamation No 300/2002

v. Ethiopianwaterresourcemanagementproclamationno1970

\footnotetext{
${ }^{4}$ Berhane \&Teklemedn (2009) at 1.

${ }^{5}$ Cummingham \& Cunningham (2012) at 14.

${ }^{6}$ Mahesh (2007) at 61.

${ }^{7}$ The Constitution of Federal Democratic Republic of Ethiopia Proclamation No_1/1995,Art 92.
} 
vi. Public Health Proclamation No 200/2000

vii. Solid Waste Management Proclamation No 513/2007

viii. Prevention of Industrial Pollution Regulation No 159/2008

ix. Institute of Biodiversity Conservation and Research Establishment/ Amendment Proclamation of Federal Democratic Republic of Ethiopia Proc No 381/2004.

\section{Ratified Laws by the House of Peoples Representative}

The Stockholm convention on persistent organic pollutants which was adopted on 22 may 2001.

The Basel convention on the control of Trans- boundary movement of hazardous waste and their disposal which was adopted on 22 marches 1989. Ethiopia also ratified amendment and protocol of Basel convention in different proclamation.

In short, Ethiopia ratified Bamako convention on proc no 355/2003, Stockholm convention on proc no 192/2000, Basel convention on proc no 279/ 2002, Basel convention amendment on proc no 356/2003 and Basel protocol on proc no $357 / 2003^{8}$.

These ratified conventions are part and parcel of national law of Ethiopia pursuant to 9/4 of FDRE constitution, the above ratified conventions are mostly applicable on trans-boundary hazardous waste pollution.

\section{Institutional Framework}

Under the EPE, different agencies are assigned to "environmental and natural resource development and management activities on the one hand and environmental protection regulation and monitoring on the other." The EPA is the leading federal environmental agency with the objective of formulating policies, strategies, laws and the standard to ensure that social and economic development activities sustainably enhances human welfare and the safety of environment. In addition, EPA is responsible for evaluating the environmental impact assessment reports of federal and inter regional projects as well as auditing and regulating there implementation. EPA is also in charge of providing technical support for environmental management in the protection to regional offices and sectorial institutions. ${ }^{9}$

The proclamation that established the EPA also requires regional states to establish their regional environmental agency. These REAs are responsible for coordinating the formulation, implementation, review and revision of regional conservation strategy and for environmental monitoring, protection and regulation. In some regions, REAs have been established as parts of other agencies, while

\footnotetext{
${ }^{8}$ Bamako Contention Ratification Proclamation; Basel Convention Amendment Ratification Proclamation; Basel Protocol Ratification Proclamation; Stockholm Convention Ratification Proclamation.

${ }^{9}$ Environmental Protection Organ Establishment Proclamation of Federal Democratic Republic of Ethiopia Proc No 295/2002, Art 6.
} 
other regions' REAs are separate institutions. All regions' city administrations have established REAs except the Somali regions, who are REAs, are continuously being restructured.

In addition to the EPA, environmental organ establishment proclamation mandated that SEU be established at every competent agency, with the responsibility of coordinating and following up activities in harmony with environmental laws and requirement. Purposes of the SEUs ensure "that environmental issues are addressed in development project and public instruments initiated by government institutions." However, SEUs have only been established so far as the ministry of mines, agriculture, water and energy, Ethiopian road authority, and Ethiopian electric power corporation, leaving most relevant federal agencies (as well as all regional ones) without environmental coordination. ${ }^{10}$

EPA in managing Ethiopian's environment, government agencies share important role with private individuals, communities, and companies. Before the enactment of the new law on civil organisations (which shrink their quality of service, number and capacity), such organisations in Ethiopia were maturing in their quality of service, geographical coverage, and creation of policy.

\section{Data Presentation, Interpretation and Analysis}

To achieve the objective of the research, researcher has selected five prominent factories which assumed to cause industrial pollution. Such factories are: - Dashen Brewery share company (herein after Dashen Brewery S.C), Habesha Brewery share company (herein after Habesha Brewery S.C), Debre Berhan Natural Spring Water S.C (Aqua Safe S.C), Debre Berhan Blanket factory P.L.C and TikurAbay Leather Shoe Factory. Indeed, questioners were distributed to communities around Concerned factories or if no community around it, to individuals who works on these areas. For better understanding, the following table shows name of factories, respondents on their age group, number of respondents on each group, sex and total number of respondents.

${ }^{10}$ Tesfaye (2012) at 64. 
Table 1.

\begin{tabular}{|c|c|c|c|c|c|c|c|c|c|c|}
\hline \multirow{2}{*}{$\begin{array}{l}\mathrm{N} \\
\mathrm{o}\end{array}$} & \multirow{2}{*}{$\begin{array}{l}\text { Name of } \\
\text { factories }\end{array}$} & \multicolumn{6}{|c|}{ Respondents age group } & \multicolumn{3}{|c|}{$\begin{array}{l}\text { Gender of the } \\
\text { respondents }\end{array}$} \\
\hline & & $15-20$ & $21-25$ & $26-30$ & $31-46$ & $>46$ & Total & $\mathrm{M}$ & $\mathrm{F}$ & Total \\
\hline 1 & $\begin{array}{l}\text { Dashen } \\
\text { Brewery }\end{array}$ & $\begin{array}{c}1 \\
(17 \%)\end{array}$ & $\begin{array}{c}1 \\
(17 \%) \\
\end{array}$ & $\begin{array}{c}1 \\
(17 \%) \\
\end{array}$ & $\begin{array}{c}2 \\
(33 \%) \\
\end{array}$ & $\begin{array}{c}1 \\
(17 \%)\end{array}$ & $\begin{array}{c}6 \\
(100 \%)\end{array}$ & $\begin{array}{c}3 \\
(50 \%) \\
\end{array}$ & $\begin{array}{c}3 \\
(50 \%) \\
\end{array}$ & $\begin{array}{c}6 \\
(100 \%)\end{array}$ \\
\hline 2 & $\begin{array}{l}\text { D/berhan } \\
\text { Blanket } \\
\text { factory } \\
\text { P.L.C } \\
\end{array}$ & $\begin{array}{c}1 \\
(20 \%)\end{array}$ & 0 & $\begin{array}{c}1 \\
(20 \%)\end{array}$ & $\begin{array}{c}3 \\
(60 \%)\end{array}$ & 0 & $\begin{array}{c}5 \\
(100 \%)\end{array}$ & $\begin{array}{c}1 \\
(20 \%)\end{array}$ & $\begin{array}{c}4 \\
(80 \%)\end{array}$ & $\begin{array}{c}5 \\
(100 \%)\end{array}$ \\
\hline 3 & $\begin{array}{c}\text { Tikur } \\
\text { Abay } \\
\text { leather } \\
\text { shoe S.C } \\
\end{array}$ & $\begin{array}{c}1 \\
(17 \%)\end{array}$ & $\begin{array}{c}2 \\
(33 \%)\end{array}$ & $\begin{array}{c}3 \\
(50 \%)\end{array}$ & 0 & 0 & $\begin{array}{c}6 \\
(100 \%)\end{array}$ & $\begin{array}{c}2 \\
(33 \%)\end{array}$ & $\begin{array}{c}4 \\
(67 \%)\end{array}$ & $6(100)$ \\
\hline 4 & $\begin{array}{c}\text { D/Berhan } \\
\text { spring } \\
\text { water } \\
\text { (Aqua } \\
\text { safe) }\end{array}$ & 0 & $\begin{array}{c}1 \\
(20 \%)\end{array}$ & $\begin{array}{c}2 \\
(40 \%)\end{array}$ & $\begin{array}{c}2 \\
(40 \%)\end{array}$ & 0 & $\begin{array}{c}5 \\
(100 \%)\end{array}$ & $\begin{array}{c}4 \\
(80 \%)\end{array}$ & $\begin{array}{c}1 \\
(20 \%)\end{array}$ & $\begin{array}{c}5 \\
(100 \%)\end{array}$ \\
\hline 5 & $\begin{array}{l}\text { Habesha } \\
\text { brewery } \\
\text { factory }\end{array}$ & $\begin{array}{c}1 \\
(33 \%)\end{array}$ & 0 & $\begin{array}{c}1 \\
(33 \%)\end{array}$ & $\begin{array}{c}1 \\
(33 \%)\end{array}$ & 0 & $\begin{array}{c}3 \\
(100 \%)\end{array}$ & $\begin{array}{c}2 \\
(67 \%)\end{array}$ & $\begin{array}{c}1 \\
(33 \%)\end{array}$ & $\begin{array}{c}3 \\
(100 \%) \\
\end{array}$ \\
\hline & Total & $\begin{array}{c}4 \\
(16 \%) \\
\end{array}$ & $\begin{array}{c}4 \\
(16 \%) \\
\end{array}$ & $\begin{array}{c}8 \\
(32 \%) \\
\end{array}$ & $\begin{array}{c}8 \\
(32 \%) \\
\end{array}$ & $\begin{array}{c}1 \\
(4 \%) \\
\end{array}$ & $\begin{array}{c}25 \\
(100 \%) \\
\end{array}$ & $\begin{array}{c}12 \\
(48 \%) \\
\end{array}$ & $\begin{array}{c}13 \\
(52 \%) \\
\end{array}$ & $\begin{array}{c}25 \\
(100 \%) \\
\end{array}$ \\
\hline
\end{tabular}

As shown on the above table, 25 questionnaires were distributed to respondents resided around the factories. For the purpose of accuracy and convenience of the research, the researcher distributed questionnaires for the respondents above fifteen years age. From whole respondents, 13(52\%) were females while remaining $12(48 \%)$ were males.

\section{Applicability of Environmental Rights}

\section{The Right to Information}

Totally, $20 \%$ of the respondents in all of the selected areas around the five stated factories responded positively that they had information regarding a plantation of the factory and the remaining mass (80\%) didn't have such information. Generally Habesha Brewery Factory which is followed by Dashen Brewery Factory is better as compared to other factories and the respondents of areas around the remaining three factories, in one or another reason aforementioned, didn't have any information about the establishment of factory. Thus, the right to information which is one of environmental rights is little observed by the concerned government bodies i.e. article 6(1) of Proclamation No295/2002 provides that the environmental protection authority has a duty to coordinate measures to ensure that the environmental objectives provided under the constitution and the basic principles set out in the environmental policy of 
Ethiopia are realised. ${ }^{11}$ As it was discussed before, a right to information can be considered as one of an environmental objectives enshrined under article 92 of the FDRE constitution. This shows that an environmental protection authority is one of the concerned government bodies which may be blamed for the stated failure to realise such environmental objective, i.e., prior consultation or prior information of the public.

\section{Right to Awareness}

Article 92(3) of the FDRE constitution again seems to incorporate the idea that public should be aware of environmental concern which may affect them.

In addition, article 6(17) of the environmental impact assessment proclamation number 295/2002 imposes duties on environmental protection authority. The first is to promote and provide non-formal environmental education program. Thus, the stated authority has a responsibility to create awareness interims of both formal and non-formal education. ${ }^{12}$

\section{Public Participation}

Public participation is emphasised throughout international and national law. It is based on the right of those who may be affected to have a say in the determination of their environmental future. ${ }^{13}$ One thing to be noted here is that the previously discussed environmental right and the right to public participation are interrelated concepts. That means the right to information can be a prerequisite for realizing the right of public awareness and public participation since one should have information to engage in any matter which affect him her in one way or another. This is why the Rio declaration provided them within one principal or provision, i.e. principle 10. Such principle says that environmental issues are best handled with participation of all concerned citizens, at the relevant level. At the national level, each individual shall have appropriate access to information concerning the environment that is held by public authorities, including information on hazardous materials and activities in their communities and the opportunity to participate in decision making processes. States shall facilitate and encourage public awareness and participation by making information with widely available. Thus, the right to information, public awareness and public participation are not mutually exclusive. Public participation, as can be inferred from the stated principles is core point under the Rio declaration to achieve sustainable development (cum with principle 1). As it was discussed before, article 92 (3) of the FDRE constitution is a provision which seems to incorporate the environmental rights which are subject of discussion in this chapter because it reads us that people have the right to full consultation, i.e. the right to information and awareness.

\footnotetext{
${ }^{11}$ Environmental protection Organ Establishment Proclamation of Federal Democratic Republic of Ethiopia at at. 6(1).

${ }^{12}$ Ibid Art 6(17).

${ }^{13}$ Berhane \& Teklemedn (2009) at 91.
} 
$15 \%$ of the respondents around the five factories where this research was conducted reflected that they have been participating in various matters concerning the relationship of factories with the community around there and the remaining mass $(85 \%)$ responded that they never exercised this right before or after the plantation of factories thereto. This shows that a pertinent government bodies were seldom committed to assume their responsibility which is entrusted to them in various international as well as national legislations.

Principle 10 of the Rio declaration prescribes that states shall facilitate and encourage public awareness and participation. Such declaration which serves as a guideline for states parties in order to protect environment and imposes a duty for states to facilitate and encourage public participation. ${ }^{14}$ Thus, public participation is significant both prior as well as after the plantation of a factory. Public participation is also best realised through participation of public in EIA. The preamble of EIA proclamation No 299/2002 states that EIA serves to bring about administrative transparency and accountability as well as to involve the public and, in particular, communities in the planning of and decision taking on developments which may affect them and its environment. ${ }^{15}$ The same law gives a public the power to review environmental study report by giving comment to it. ${ }^{16}$ Similarly, article 1(1) of the same proclamation provides that the environmental protection authority or the relevant regional environmental agency shall make any environmental impact study report accessible to the public and society comments on it. ${ }^{17}$ Sub article 2 of the same article also states that the above mentioned government bodies shall ensure that the comments made by the public and in particular by the communities likely to be affected by the implementation of a project are incorporated in to the environmental study report as well as in its evaluation.

Another legal document, which poses an obligation on the states to create a conducive environment for public participation; is ANRS proc no 181/2011. The same proclamation states that, the harmed part of society may take part in the conduct of environmental impact assessment. The power is also given for public in terms of public comments. ${ }^{18}$ Thus, all the stated laws directly or indirectly shows that public participation is a crucial element which should be exercised by the community before the plantation of factory interims of environmental impact assessment and after the plantation of a factory in various matters affecting them.

Even though various legislations as stated above impose a duty up on the government to facilitate public participation which is very important to protect the environment including article 93(4) of the FDRE constitution, the performance in Debre Berhan Town is very low so that it is possible to say those government bodies, environmental protection Authority, Amhara National Regional State Environmental Protection, Rural land Administration and Use Bureau, North Shoa

\footnotetext{
${ }^{14}$ Rio Declaration on Environment and Development (1992) at principle 10.

${ }^{15}$ Environmental Impact Assessment Proclamation of Federal Democratic Republic of Ethiopia Proc, preamble.

${ }^{16}$ Ibid Art19(2).

${ }^{17}$ Ibid Art 15(1).

${ }^{18}$ Amhara National Regional State Environmental Impact Assessment Proclamation Art 12(2).
} 
Zone Environment, Rural Land Administration and Use Office, Debre Berhan City Administration Environmental Protection and Land Administration Offices has failed to assume their responsibility provided under various legislations.

\section{Types of Pollution which found in Study Area}

The general meaning of various types of pollution were addressed under the previous chapter. This section comes up with type of pollution which is prevalent in Debre Berhan town specifically around the areas where the five factories on which the research was

Conducted situate. Accordingly the research found that there are four types of pollution in Debre Berhan. These are: -Water pollution, Air pollution, Land pollution and Noise pollution

In order to discuss the prevalence of these types of pollution, it is important to have a general overview of the table below.

\section{Question: What types of industrial pollutions emitted from factories?}

Table 2.

\begin{tabular}{|c|c|c|c|c|c|c|c|}
\hline \multirow{2}{*}{ Name of the factories } & \multicolumn{7}{|c|}{ No. of respondent per response } \\
\hline & Water & Air & Land & Noise & All p. & No & Total \\
\hline Dashen Brewery S.C & $\begin{array}{c}6 \\
(100 \%)\end{array}$ & $4(67 \%)$ & 0 & 0 & - & - & $\begin{array}{c}6 \\
(100 \%)\end{array}$ \\
\hline $\begin{array}{l}\text { Debre Berhan Blanket } \\
\text { P.L.C }\end{array}$ & $5(100 \%)$ & $1(20 \%)$ & 0 & 0 & - & - & $\begin{array}{c}5 \\
(100 \%)\end{array}$ \\
\hline $\begin{array}{l}\text { Tikur Abay Leather } \\
\text { Shoe S.C }\end{array}$ & $\begin{array}{c}6 \\
(100 \%)\end{array}$ & $\begin{array}{c}6 \\
(100 \%)\end{array}$ & $1(17 \%)$ & $\begin{array}{c}1 \\
(17 \%)\end{array}$ & $\begin{array}{c}1 \\
(17 \%)\end{array}$ & 0 & $\begin{array}{c}6 \\
(100 \%)\end{array}$ \\
\hline $\begin{array}{l}\text { Debre Berhan Natural } \\
\text { Spring Water PLC } \\
\text { (Aqua Safe) }\end{array}$ & $\begin{array}{c}5 \\
(100 \%)\end{array}$ & $3(60 \%)$ & $\begin{array}{c}5 \\
(100 \%)\end{array}$ & 0 & 0 & 0 & $\begin{array}{c}5 \\
(100 \%)\end{array}$ \\
\hline Habesha Brewery S.C & $\begin{array}{c}3 \\
(100 \%)\end{array}$ & $1(33 \%)$ & 0 & 0 & 0 & 0 & $\begin{array}{c}3 \\
(100 \%)\end{array}$ \\
\hline Total & $\begin{array}{c}25(100 \\
\%)\end{array}$ & $\begin{array}{c}15 \\
(60 \%)\end{array}$ & $6(24 \%)$ & $1(4 \%)$ & $\begin{array}{c}1 \\
(4 \%)\end{array}$ & 0 & $\begin{array}{c}25 \\
(100)\end{array}$ \\
\hline
\end{tabular}

\section{Water Pollution}

Factories which the research was conducted emit liquid wastes to the river around the factory and that wastes in turn pollutes the river. This is a way how water pollution occurs in Debre Berhan Town according to the observation of the researchers. 
In general, $100 \%$ of the respondents around the areas where the research was conducted said that water pollution is highly prevalent in Debre Berhan Town.

\section{Air Pollution}

Totally, $60 \%$ of the respondents around the areas where the research was done replied that there exists air pollution resulting from the factory.

\section{Land Pollution}

The degree of land pollution is low as compared to the previously discussed types of pollution which show that only $24 \%$ of the total number of respondents in all areas where the research was conducted stated that the factories in Debre Berhan are polluting the land.

\section{Noise Pollution}

In general, noise pollution is little reported by the respondents in Debre Berhan Town, specially, where the research was conducted that is only $4 \% .17 \%$ of the respondents around TikurAbay Leather Shoe Factory S.C. replied that all types of pollution aforementioned are prevalent at that area. That is $4 \%$ of the total respondents in areas where the research was conducted (Debre Berhan Town).

Thus, it is possible to say that all kinds of pollution exist in Debre Berhan Town due to the failure of government body to assume their responsibility as discussed before and factories to take appropriate measures to avert or mitigate pollution that is their failure to observe various legal instruments which obliges them to do so (to be discussed later).

\section{Causes of Pollution}

Accordingly, FDRE constitution states that the government of Ethiopia shall endeavor to ensure that all Ethiopians live in clean and healthy environment. ${ }^{19}$ But pollution by its nature is an antagonistic event which inhibits the realisation of the stated right granted to all persons.

Polluting the environment by violating the relevant environmental standard is strictly prohibited under article 3(1) of pollution control proc. 300/2002. Article 4(1) of the same proclamation states that; the generation, keeping, storage, transportation, treatment or disposal of any hazardous waste; without a permit from the environmental protection authority or the relevant regional environmental agency is prohibited. In addition, government and citizens shall have the duty to protect the environment pursuant to articles 92(4) of the FDRE constitution.

The preamble of proc.300/2002 also provides that the protection of the environment and the safeguarding of human health and wellbeing as well as the

\footnotetext{
${ }^{19}$ The Constitution of Federal Democratic Republic Of Ethiopia Proclamation No_1/1995, Art 92(1).
} 
maintaining of the biota and the aesthetic value of nature in particular, are the duty and responsibility of all. ${ }^{20}$

Therefore, it can be understood that the concerned body for the prevention of industrial pollution, which can be considered as one part of environmental protection, are the government, factory and the society as discussed above. Each has their own duty and responsibility to prevent industrial pollution.

The researcher found that the stated legal frameworks are not satisfactorily observed so that industrial pollution is prevalent in Debre Berhan Town. Accordingly, the cause of industrial pollution in this town emanates from various factors. These are!-

- Failure of factories to take appropriate measures to eliminate or mitigate industrial pollution i.e. non-observance of factories to legal frameworks for the production of environment, specially, industrial pollution.

- Failure of the pertinent government bodies to assume their responsibility prescribed under various legislations.

- Failure of society to exercise their environmental rights envisaged in various legislations.

In order to analyse each of the factors mentioned above, having an incite from the table below is necessary

\section{Question: By whose fault do you think pollution emanates?}

Table 3.

\begin{tabular}{|l|c|c|c|c|c|c|}
\hline \multirow{2}{*}{ Name of the factories } & \multicolumn{5}{|c|}{ No. of respondents per response } \\
\cline { 2 - 7 } & Factory & $\begin{array}{c}\text { Concerned } \\
\text { gov.t body }\end{array}$ & Society & All & Others & Total \\
\hline Dashen Brewery S.C & $\begin{array}{c}4 \\
(67 \%)\end{array}$ & $6(100 \%)$ & 0 & 0 & - & $\begin{array}{c}6 \\
(100 \%)\end{array}$ \\
\hline $\begin{array}{l}\text { DebreBerhan Blanket } \\
\text { P.L;C }\end{array}$ & $3(60 \%$ & $2(40 \%)$ & 5 & 0 & - & $\begin{array}{c}5 \\
(100 \%)\end{array}$ \\
\hline $\begin{array}{l}\text { TikuAbay Leather Shoe } \\
\text { S.C }\end{array}$ & $\begin{array}{c}5 \\
(83 \%)\end{array}$ & $4(67 \%)$ & $\begin{array}{c}1 \\
(17 \%)\end{array}$ & $1(17 \%)$ & 0 & $\begin{array}{c}6 \\
(100 \%)\end{array}$ \\
\hline $\begin{array}{l}\text { DebreBerhan Natural } \\
\text { Spring Water PLC } \\
\text { (Aqua Safe) }\end{array}$ & $\begin{array}{c}5 \\
(100 \%)\end{array}$ & $5(100 \%)$ & $\begin{array}{c}2 \\
(40 \%)\end{array}$ & $2(40 \%)$ & 0 & $\begin{array}{c}5 \\
(100 \%)\end{array}$ \\
\hline $\begin{array}{l}\text { HabeshaBreweryFactory } \\
\text { S.C }\end{array}$ & $\begin{array}{c}3 \\
(100 \%)\end{array}$ & $3(100 \%)$ & $\begin{array}{c}1 \\
(33 \%)\end{array}$ & $1(33 \%)$ & 0 & $\begin{array}{c}3 \\
(100 \%)\end{array}$ \\
\hline Total & $20(80$ & $20(80 \%)$ & $\begin{array}{c}9 \\
(36 \%)\end{array}$ & $4(16 \%)$ & 0 & $\begin{array}{c}25 \\
(100 \%)\end{array}$ \\
\hline
\end{tabular}

${ }^{20}$ Environmental Pollution Control Proclamation of Federal Democratic Republic of Ethiopia, preamble. 


\section{Measures Taken to Control Industrial Pollution}

So long as the plantation and expansion of the industries in the town was not questionable, the effects (side effects) of the industry were also unavailable. In relation to that to effectively assess the measures, researcher has classified measures into three parts:

- Precautionary measure

- Preventive measures and

- Remedial measures

\section{Precautionary Measures}

Environmental law bestows both pertinent environmental protection and land administration bodies and proponents of projects with obligation to take precautionary measures to control industrial pollution. Researcher has gathered data on the type and manner of precautionary measures taken by both factories and pertinent environmental protection organs by interviewing each of them.

\section{a. Precautionary measures taken by offices of North Shoa Zone and Debre Berhan Town Environmental Protection and Land Administration Bodies}

Environmental law provides so many types of precautionary measures which should be taken by the pertinent environmental protection bodies i.e. they have oblivion to formulate standards based on scientific and environmental principles i.e. Sewerage, air quality, type and amount of substances deposited to soil, water management system etc. ${ }^{21}$

Other precautionary measures that should be taken by the concerned bodies are; approval and assessing of EIA study conducted and initiated by the proponents of the projects. ${ }^{22}$ The body have also obligation to monitor and ensure the implementation of the study. ${ }^{23}$

When we come to practical precautionary measures taken by the North Shoa Zone or in Debre Berhan Town, the North Shoa Zone the Department of Environmental Protection and Land Administration have taken the precaution nary measures such as before licensing assesses the EIA study conducted by proponents of the project (factory). ${ }^{24}$ They also monitor factories to take mitigation measures. The office of Debre Berhan Town Environmental Protection and Rural Land Administration also has taken similar measures with zone.

However, the monitoring and review system of both zonal department and town office was weak and mostly concerned and focus on desk rather than field review. ${ }^{25}$ It is obvious that for the effectiveness field reports and review have great

\footnotetext{
${ }^{21}$ Ibid, art 6(1).

${ }^{22}$ Amhara National Regional State Environmental Impact Assessment Proclamation, Art 4(3).

${ }^{23}$ Ibid, Art 15(1).

${ }^{24}$ Ibid.

${ }^{25}$ An interview held with Ato Samuel Weldehana.
} 
role than that of desk review, since in field review the authority directly observers the implementing of the EIA study report conducted by the concerned factory.

\section{b. Precautionary Measures Taken by Factories Operating in Debre Berhan Town}

Law also provides obligation on the part of proponents of the projects (factory) to take precautionary measures. Thus, any person shall take appropriate precaution to prevent any damage to the environment or human health or well beings. ${ }^{26}$ In that proponents of the project shall before entering into force deliver the study report of EIA to the bureau of the pertinent office of environmental protection and land administration ${ }^{27}$ In addition to that it shall ensure the availability of occupational health services of employers. ${ }^{28}$

Standing from these legal requirements (precautionary measures) that should take by the factories, researchers have analysed the existing practical application of such laws by the factories in Debre Berhan Town. Thus, as far as the EIA study was concerned the representatives of each factory accepts or certainly on the existence of EIA study on the project. However Debre Berhan Blanket P.L.C and TikurAbay Shoe S.C didn't know about when and how the EIA study was Conducted, because of the fact that the project was not established and planted by the now existing proponents (ownership of the two factories were transferred from former established owners). On the other hand, Debre Berhan Natural Spring Water, Dashen Brewery and Habesha Brewery were certain about the conduct of EIA assessment, because these factories were established on very recent. Blanket Factory and TikurABay Shoe Share Company shall have obligation to make study of environmental monitoring plan, deriver to the pertinent body of environmental protections and land administration pursuant to art 9(2) of EIA Proc No 181/2011. However, still today except the supervisory report, there was no formal study completed and delivered to the pertinent body, as what understood from their reflection.

Other precautionary measures taken by the factories in the town were safety (employment safety) measures. Such methods differ from one project to another based on the nature of the project. For example in Tikur Abay Shoe S.C use employees safety measures such as musk and glove while in Blanket factory they uses dust musk, eye glass, leather glove, plastic shoes and wear and tear goggle mandatory. Both Habesha and Dashen Brewery uses ear goggle and eye glass while Debre Berhan Natural Spring Water S.C uses no as such precautionary measures on employees. In overall Blanket PLC was safer than that of others, because it uses so many safety measures. However some factories deny the fact that importance of precautionary measures and they were reluctant to use safety measures like Debre Berhan Natural Spring Water. This is basically against what law provides.

\footnotetext{
${ }^{26}$ Environmental Pollution Control Proclamation of Federal Democratic Republic of Ethiopia, Proc Art 4(2).

${ }^{27}$ Amhara National Regional State Environmental Impact Assessment Proclamation No- Art 9(1).

${ }^{28}$ Public Health Proclamation Federal Democratic Republic of Ethiopia Proc Art 11(1).
} 


\section{Prevention Measures}

Similar to precautionary, it is obligation of both the pertinent body of the environmental protection and land administration and proponents of project as well. For the convenience of clarification, researcher has classified preventive measures into two i.e. measures taken by pertinent body of the environmental protection and measures taken by factories.

\section{a. Pollution Preventive Measures Taken by North Shoa Zone and Debre Berhan Town Environmental Protection and Land Administration Offices}

The cumulative readings of article 4, 7(1\&2), 8(2) of pro No299/2002 and Art 4(3) of EIA Proc No 18/2011 of Amhara National Regional State, Pertinent Environmental Protection and Land Administration Office should assess, evaluate and verity the incorporation of issues related to effects of projects, incorporation of nature, amount and content of the pollutants, etc in the EIA study. ${ }^{29}$

In relation to that when we see the practical truth in the town, the North Shoa Zone environmental protection and land administration office review EIA study report conducted by proponents of projects review, assess and audit the incorporated mitigation measures, follow up the enforcement of safety measures, follow up the existence and functioning of treatment plant and follow up the implementation of whole contents of the EIA study report of the concerned proponents of projects. In review they take may be both desk (with in office by using document) or field view (by going and observing the proponent projects) it also monitor and audit the functioning of liquid treatment plant dray wastage disposal mechanisms and gives feed backs.

Currently, the office also started to identify industry zone within one area and with that industry zone it made cluster by locating factories producing identical and similar as well as related products in one area. For instance, food factories i.e. powder, meat milk etc. in one area while leather, shoe, glass medicine etc. factories on the other place. ${ }^{30}$ Debre Berhan Town environmental protection and land administration office also performs similar functions within town in collaboration with zonal. ${ }^{31}$ However, the great issue in here is does these mechanisms were really resulted the prevention of pollution, we will see them on subsequent analysis below.

\section{b. Preventive Measures Taken by the Factories Operating in Debre Berhan Town}

Article $8(2)$ of the EIA proc No $299 / 2002$ provides that the proponents of project should conduct study by incorporating at least minimum standards, nature and content of factories. Similarly, Art 3(3) of pollution proclamation provides that any person engaged in any field of activity which is likely to cause pollution or any other environmental harm (hazard) shall install a sound technology that avoids

\footnotetext{
${ }^{29}$ Environmental Impact Assessment Proclamation of Federal Democratic Republic of Ethiopia Proc No 299/2002, Art 8 (2,a \& b).

${ }^{30}$ An interview with Samuel Weldehana, E.C

${ }^{31} \mathrm{An}$ interview with Ato Dereje Kura,
} 
or reduce, to the required minimum, the generation of waste and when feasible apply method for the recycling of waste.

Standing from the above and similar provisions, researchers have gathered data from the aforementioned five factories functioning in Debre Berhan Town, to search whether they apply the law in their project or not to prevent industrial pollution. Now on this section, we will analyse the data gathered from each factory one by one.

\section{c. Prevention Measures Taken by Tikur Abay Leather Shoe S.C}

Tikur Abay Leather Shoe S.C factory, which have got ownership to the company before two years or in 2006 E.C form the private limited company, have taken so, many pollution prevention mechanisms to control the pollution. It reconstructed prior treatment plant in a new manner. This treatment plant was now fully functioning primary (chemical treatment) which filters waste water and neutralises such water components. The aeration system and ventilator are also available. The windows of the factories functioning house is open for the ventilation purpose. $^{32}$

The solid wastes are buried and since it is protein in nature (the result of hides), it is quickly decomposed within two or three years. ${ }^{33}$ Tikur Abay leather shoe factory also renewed existing liquid water tunnel which elongated from factory to Baresa River (about 2K.M long). This tunnel was before its renewal 25 C.M wide and even broken and waste substances were flowing on the area where human being lives. To prevent such pollution, factory have made tunnel wider (increased its size to 50 C.M wide) and such tunnel was now galvanised and not easily exposed to damage. In addition to that the factory used chemical pamper and exhauster. ${ }^{34}$ However, the liquid wastes are directly released to Baressa River. From the amount 5000 L Per day used, half of the water was released as waste and such wastes entered into Baresa River. Such wastes pollute the river unequivocal manner. Even though the company has tried and taken above mentioned preventive measures, it is not tried to give solution to the pollution of Beresa River and even nothing was planned for this purpose.

These activities of Tikur Abay leather shoe S.C was contrary to the art 12(2) of public health proc. No 200/200 which provides to that no person shall dispose solid liquid or any other wastes in a manner which contaminates the environment or affect the heath of the society. On this issue, environmental protection organ of both zone and town where not have taken any measure even though they have given data for the researchers as fully functioning their part. For that issue the environmental protection and land ministration office of the town raise the defense that we have no capacity to take any preventive measure since the Tikur Abay SC was licensed by regional bureau. But it's contrary to the Art. 13(2) of the proclamation no. 279/2000 which provides unless pollutants were treated effectively before release or discharge to water such discharge is prohibited, and Art. 3(5) of pollution control proclamation no. 300/2002 which authorises

\footnotetext{
${ }^{32} \mathrm{An}$ interview with Ato Ermias Wesenu,

${ }^{33}$ Ibid.

${ }^{34}$ Ibid.
} 
concerned body to take necessary preventive measure to control industrial pollution. This clearly reflects what is missed by factory and concerned body as well.

\section{d. Prevention Measures Taken by D.B. Blanket P.L.C}

Debre Berhan Blanket Factory has also taken preventive measure in addition to precautionary measures. There is treatment plant like other factories and wastes are treated within pond-- then discharged by zigzag about 50M outside and-- then released to Beresa River. However, the treatment plant was not effectively functional and proponent was not still renewed treatment plant.40 Researchers have concluded that it is against Art. 12 of Pollution Control Regulation no. $159 / 2008$ which provides that existing proponent of the project shall comply with the requirements provided under proclamation and regulation within 5 years. Because so long as the factory was established in 1940s, it is very necessary to review the treatment plant. It is not only the failure of the factory but also concerned environmental protection organ as well. But interesting thing is that the company was in the process of reviewing the treatment plant for near future.

Another preventive mechanisms used by the factories were, it reduced the amount of wastes which were released to Beresa River (Before privatised 50-60 thousand litres water liquid waste were released per day in three shifts) while now it is released only 3 times per week. The dry wastes, except paper, other remained pieces become recycled and used to produce foam while papers were collected and burnt. $^{35}$

\section{e. Prevention Measures Taken by Debre Berhan Natural Spring Water S.C}

Debre Berhan Natural Spring Water PLC also have taken some preventive measures such as treatment plant which functions as follows; source of waterreserve tanker-sand filter-activated carbon with micro carbon by using $\mathrm{Co}_{2}-$ ultralayer for ozone gas generator- pure tanker-pure water. In this process, there might be back flow water is also pure water and used for steam generator and for packaging purposes rather than leaving it as a mere wastage. ${ }^{36}$ The factory proponent also burns wastes remained from labelling and packaging materials. Perform (plastic bugs) and cups are dry wastes of the factory are buried and burnt.

Even though the quality control head of the factory have given above mentioned information about factory, researches have observed different things i.e. waste water were released without any tunnel to the river around it. These liquid wastes have a bad smell, this pollutes the human environment. In addition to that, plastic bags and cups with its pieces were openly thrown around it. Because of these reason, researcher has understood that quality control of the factory giving information what ought to be done rather than what was taken by them. This is against the law which obliges factories to collect and recycle plastic and plastic bags. $^{37}$

\footnotetext{
${ }^{35} \mathrm{An}$ interview done with Ato Getachew.

${ }^{36}$ An interview with Roza Seifu.

${ }^{37}$ Industrial pollution control reg no 159/2002,Art 7 and 8.
} 


\section{f. Preventive Measures Taken by Habesha Brewery Factory}

Like that of another factory, it also uses treatment plant to neutralise the waste it releases. It followed the procedures that; waste-temporary storage (in this if the waste is acid, PH will be added or if it is base HCL will be added to neutralise it) anaerobic proof (without oxygen or it is closed system)--Aerobic (by using oxygen) in these process it takes about 7 hours before released to the water tanker, then finally relatively neutralise waste will be released to the water (river) through tunnel. ${ }^{38}$ They also uses aeration system by using cyclone which purifies air and only purified air will be released while dust part is collected in the container. Glasses and its broken were recycled while dry wastes become disposed and burned. $^{39}$ The researcher has also observed these preventive mechanisms and concluded that it is better than other factories by the usage of preventive measure. In addition to that, it is also planned to provide and make suitable condition for farmers around it to use water released from factory for irrigation purpose.

\section{g. Preventive Measures Taken by Dashen Brewery Factory}

As that of Habesha Brewery Factory, Dashen Brewery established treatment plant to neutralise the wastes released from the factory. However, unlike Habesha Brewery, its treatment plant is not fully functioning. ${ }^{40}$ In additions to that, the liquid wastes are released by factory openly without any tunnel and contaminates water (river) around it. This is again contrary to the law that prohibits discharge of wastes to the river (water) without treatment and law that prohibits dispose of contaminating substances that can harm human health, environment and wellbeing. ${ }^{41}$

Researchers also have observed the fact that the waste of Dashen Brewery pollutes environment because of its open discharge to water without tunnel or even ditch. On the other hand, the factory in collaboration with Habesha Brewery Factory planned to provide waste water passed through treatment plant for irrigation purpose and 400 hectares of farm land will be benefited from such irrigation as reported by Dereje Kura. But now the environment was under hardship because of pollution by Dashen Brewery Factory.

In over all, the factories such as Habesha Brewery Factory and in some extent TikurAbay Leather Shoe Factory used better mechanism than other while Dashen Brewery Factory is under worst condition in the prevention of industrial pollution. But the researchers have concluded that it is not only because of the weakness and failure of factory to observe legal frameworks for pollution control and comply with it, but also pertinent environmental protection body as well. Because pertinent body should monitor audit and inspect the implementation project according to cited EIA study. ${ }^{42}$ In relation to that, a mere authorisation of the study shall have

\footnotetext{
${ }^{38}$ An interview with Ato Amsalu,Fenta,

${ }^{39}$ Ibid.

${ }^{40}$ An interview with Ato Dereje Kura.

${ }^{41}$ Public Health Proclamation Federal Democratic Republic of Ethiopia Proc No_200/2000, Art 12(2).

${ }^{42}$ Amhara National Regional State Environmental Impact Assessment Proclamation rt 15(1).
} 
no effect unless implemented and it shall not exonerate the proponents of project from liability. ${ }^{43}$

\section{Extent of Industrial Pollution in Debre Berhan Town}

The researcher has distributed questioners and interviewed society and other concerned government bodies. Thus, the following table shows the responses of the communities around the respective factories to the question.

\section{Question: What about the extent of industrial pollution?}

Table 4.

\begin{tabular}{|l|c|c|c|c|c|}
\hline \multirow{2}{*}{ Name of factories } & \multicolumn{5}{|c|}{ No. of respondents per their response } \\
\cline { 2 - 6 } & Increasing & Decreasing & Constant & $\begin{array}{c}\text { Totally } \\
\text { eliminated }\end{array}$ & Total \\
\hline Dashen Brewery S.C & $3(50 \%)$ & $1(17 \%)$ & $2(33 \%)$ & 0 & $6(100 \%)$ \\
\hline $\begin{array}{l}\text { Debre Berhan Blanket } \\
\text { P.L.C }\end{array}$ & $2(40 \%$ & 0 & $3(60 \%)$ & 0 & $5(100 \%)$ \\
\hline $\begin{array}{l}\text { Tikur Abay Leather } \\
\text { Shoe S.C }\end{array}$ & $3(50 \%)$ & 0 & $3(50 \%)$ & 0 & $6(100 \%)$ \\
\hline $\begin{array}{l}\text { Debre Berhan Natural } \\
\text { Spring Water P.L.C } \\
\text { (Aqua Safe) }\end{array}$ & $4(80 \%)$ & 0 & $1(20 \%)$ & 0 & $5(100 \%)$ \\
\hline Habesha Brewery S.C & 0 & 0 & $3(100 \%)$ & 0 & $3(100 \%)$ \\
\hline Total & $12(48 \%)$ & $1(4 \%)$ & $12(48 \%)$ & 0 & $25(100 \%)$ \\
\hline
\end{tabular}

The above table shows the response of the communities for the question how about the extent of industrial pollution in your locality (whether industrial pollution was increasing or decreasing or not changed or totally eliminated. Thus, from respondents around Dashen Brewery Factory, 50\% responded the extent of pollution was increasing while $17 \%$ responded decreasing while $33 \%$ responded that there was no change. $40 \%$ of the respondents around Debre Berhan Blanket Factory PLC responded increasing while $60 \%$ answer no change.50\% of the respondents around Tikur Abay leather shoe S.C answered increasing while $20 \%$ said no change. $80 \%$ of the respondents to Debre Berhan Natural Spring Water responded increasing while $20 \%$ said no change. $100 \%$ the respondents of Habesha Brewery Factory responded no change.

Totally, $48 \%$ responded increasing and $48 \%$ responded no change and only 4\% responded decreasing. From these, it is understandable that only Habesha Brewery Factory respondents responded only no change while only 17\% of that of Dashen Brewery Factory said decreasing, the remaining others responded

\footnotetext{
${ }^{43}$ Ibid, art 4(3).
} 
increasing and no change. From this, researchers have concluded that even though factories and pertinent bodies argued that they have functioning and practicing in light with pertinent laws, it is unsatisfactory to community and seems they have not taken effective preventive measures. Debre Berhan Town Environmental Protection and Land Administration Office agreed and accepted and even unequivocally proved the increment of the extent of industrial pollution from time to time. ${ }^{44}$ In short, it is manifestation and reflection to the weak implementation or failure of implementation of legal frameworks for the control or prevention of industrial pollution.

\section{The Effects of Industrial Pollution in Debre Berhan Town}

In this section, researcher has analysed the effect of industrial pollution and remedial measures which have taken by the societies on one hand and by pertinent environmental protection and land administration body in Debre Berhan Town. In order to know, researchers have asked communities around the factories through questionnaires whether there is effect of pollution on their localities. Accordingly, more than $90 \%$ of the respondents responded by saying there was effects of the industrial pollution in the town. Some of these effects raised by respondents were; communities around Dashen Brewery Factory became out of the river around because of pollution by such factory and their animals were subjected to diseases because of drinking water polluted by the pollutants, even though it was not scientifically proved. On the other hand, communities around Beresa River were out of the use of the river because of its contamination by the discharge of waste form Leather Factory, Blanket Factory and others.

Societies around Leather Factory were subjected to common cold because of air pollution, they were also to even eat their meal at their home freely because of industrial pollution (bad smell emanates from the factory).In relation to that, if such effects of pollution were resulted from the factories, the next issue will be what remedial measures have taken by communities and pertinent environmental protection body of the town. This is because art 11(1 and 2) of pollution control proc no 300/2002 with Article 10(1-3) of industrial pollution control regulation no $159 / 2008$ stipulates that the right to compliant against pollution at the authority or relevant environmental agency and if not satisfied by the response of such authority, he/she can appeal to highest authority and even to court. Indeed, practically whether society in Debre Berhan Town exercise these rights against industrial pollution or not is better understood with the table below.

\footnotetext{
${ }^{44}$ An interview with AtoDerejeKura.
} 
Question: Is there any time that lodged a complaint or reported at authority?

Table 5.

\begin{tabular}{|l|c|c|c|c|c|c|}
\hline \multirow{2}{*}{ Name of factories } & \multicolumn{6}{|c|}{ No. of respondents per their response } \\
\cline { 2 - 7 } & Yes & Percent & No & Percent & Total & Percent \\
\hline Dashen Brewery S.C & 5 & $83 \%$ & 1 & $17 \%$ & 6 & $100 \%$ \\
\hline $\begin{array}{l}\text { DebreBerhan Blanket } \\
\text { P.L.C }\end{array}$ & 2 & $40 \%$ & 3 & $60 \%$ & 5 & $100 \%$ \\
\hline $\begin{array}{l}\text { TikurAbay Leather } \\
\text { Shoe S.C }\end{array}$ & 3 & $50 \%$ & 3 & $50 \%$ & 6 & $100 \%$ \\
\hline $\begin{array}{l}\text { DebreBerha } \\
\text { n Natural Spring Water } \\
\text { P.L.C (Aqua Safe) }\end{array}$ & 0 & 0 & 5 & $100 \%$ & 5 & $100 \%$ \\
\hline $\begin{array}{l}\text { Habesha Brewery S.C } \\
\text { Total }\end{array}$ & 0 & 0 & 3 & $100 \%$ & 3 & $100 \%$ \\
\hline
\end{tabular}

Thus, in order to understand the application of such, researcher distributed the questionnaire for the respondents of concerned factories. For this, respondents around Dashen Brewery Factory responding by $83 \%$ yes and $17 \%$ no while from respondents of Blanket Factory $40 \%$ answered yes and $60 \%$ said No, form among respondents on leather factory $50 \%$ by $50 \%$ yes and no respectively. Participants responding on Debre Berhan Natural Spring Water S.C by $100 \%$ said no by saying 'we have never complained against pollution' and similarly $100 \%$ of respondents around Habesha Brewery Factory totally responded no. From these data, one can understand that the only respondents on Dashen Brewery Factory and in some extent Leather Shoe Respondents applied above mentioned right(right to complaint) better than others. In addition, the table shows that from total number of respondents, only $40 \%$ responded yes (used his/her right to complaint at authority).This indicates that even though pollution and its effects existed in the town, society was not willing to complain to authority still (Hidar 24/2008 E.C). No case was appeared before the court as a result of industrial pollution in the town. ${ }^{45}$ This shows either unawareness of society or reluctant and negligence or thinking (no response and solution for it form the government body).The last issue what to be raised in this subsection was the type and situation in which the remedial measures taken by pertinent environmental protection body. This obligation emanates from Art 3(5) of the pollution control proclamation no. 300/ 2002 which states that when any activity poses a risk to a human health or to the environment, the authority or relevant regional agency shall take any necessary measures up to relocation or closure of any enterprise in order to prevent harm. In

\footnotetext{
${ }^{45}$ An interview with Ato Fekadu Negash.
} 
addition to that pursuant to Art 11 of the procn.300/2000 with its regulation no 159 on art 10, authority or relevant regional agency shall take effective measures to the complaint without proving vested interest. Furthermore, pursuant to Article 7(2) of the same regulation; competent organ shall suspend or cancel license of factory if it causes series pollution. Concerning the practical remedial measures taken by the offices of environmental protection and land administration of zone and town, such measures taken by this offices were; relocation of some factories that may potentially pollute other factories. For instance, glass and medicine factories were relocated and suspended license as a result of causing pollution to food factory (meat, powder, and milk near the above mentioned factories) around them. ${ }^{46}$

However, above mentioned remedial measures, pertinent environmental protection body have not given any actual response to the complaint lodged by the community around factories, i.e., from Dashen Brewery Factory and Leather Factory. But pertinent government organs have not taken any satisfactory measures in response to the complaint. This clearly indicates the weakness and lack of effective enforcement of aforementioned laws.

\section{Challenges to Control Industrial Pollution}

On the preceding sections, the researcher has presented and analysed the practical applicability in Debre Berhan Town and weakness on the part of pertinent environmental protection organ, factories and societies as well. However, on their part pertinent environmental protection and land administration offices, factories and societies provides challenges to them that caused gap in the implementation of laws on protection of industrial pollution. Such challenges are:

- Lack of strong environmental protection office in the town because of its infancy (since it was become independent from agricultural office after 2005) and there was still no environmental legal expert in the office of the town.

- Lack of awareness on the side of proponents of the project about the sustainability environment for the future generation rather they only focus on their project and willing to maximise their profit.

- Lack of research centre to conduct research to know and check the existence, cause and effect of the pollution

- Difficulty to relocate factories which were planted in earlier time (before current reform) on the unsuitable location, for example, there is difficulty on the part of government either to relocate leather factory which functioning in kebele 07 or residents around it. Because it is very difficult and even seems impossible to relocate.

- Lack of active commitment of society to control industrial pollution in collaboration with government, factories and other concerned bodies.

\footnotetext{
${ }^{46}$ An interview with Ato Samuel Weldehana,
} 
- Shortage of electric power, which was resulted the back flow of the liquid waste to the unwanted places because of malfunctioning (stoppage) of chemical pumper which is activated by electric power.

- Since officers or workers on environmental protection and land administration are not graduates on fields related to environment and have no deep knowledge on it, most of the time they were exposed to deception by technical words used by proponents of projects and lacks ability to identify the existence and extent of pollution by the project.

- Lack of awareness on part of societies about mitigating measures and relativity of the side effects of factories.

- Gaps on the part of concerned government body on rendering of public awareness, information and creation of the conducive environment to public participation on decision making process.

\section{Conclusion}

The duty of government to make relevant information available to the public is little observed by the concerned government bodies and the society is not addressed with the right to information to the extent that the law requires.

Most of the society around factories didn't take any training or education with respect to any issue related with the factory.

Public participation is insignificant both prior as well after the plantation of the factory. Government is better in realizing public participation through EIA but public participation after the plantation of a factory is very low.

EPA, Amhara National Regional State Environmental Protection, Rural Land Administration and Use Bureau, Zone Environmental Protection, Land Administration and Use Office and Debre Berhan City Administration Environmental Protection and Land Administration Office has failed to assume their responsibility, entrusted to them by various legislations to the extent as required by law.

Four types of pollutions have prevailed in Debre Berhan Town. These are water pollution, air pollution, land pollution and noise pollutions. All types of pollutions are emanated from the failure of the government, the factories and the society to act as the relevant laws direct them.

Various measures were taken by the government and factories to prevent and reduce pollution. Such measures taken are classified as precautionary measures, preventive measures and remedial measures.

The extent of industrial pollution is reported to increase from time to time. Effect of all types of pollution stated above may be inflicting harm on health of human beings, animals and plants, complaints lodged and various remedial measures which were given by relevant government organs at different levels.

The overall challenges for the protection of industrial pollution are:

i. Factories highly focus on profit making process and their observance to legal frameworks on protection of industrial pollution is very low. 
ii. Lack of coordination among the pertinent government bodies, factories and the society in order to prevent industrial pollution and comply

iii. With the legal frameworks on protection of industrial pollution.

\section{References}

Berhane, T. \& M. Teklemedn (2009). Environmental law teaching material, Mekele University, Ethiopia.

Cunnungham, W.P. \& M.A. Cunningham (2012). Environmental Science: A Global Concern, $12^{\text {th }}$ ed. New York, NY: McGraw- Hill business unit of Mc Graw-Hill companies Inc.

Mahesh, M. (2007). Legal Control of Environmental Pollution. New Delhi Publishing Press.

Senger, D.S. (2007). Environmental law. New Delhi: Prentice-Hall of India Pvt.Ltd Publishing press.

Tesfaye, A. (2012). 'Environmental Impact Assessment and Monitoring under Ethiopian Law' in Haramaya Law Review 1:103-124.

\section{Interviews}

An interview held with Ato Amsalu, Fenta, Envirnmental senor chemist of Habesha Brewerys on 20/03/2008.

An interview held with Ato Dereje Kura, DB city EP and land administration department coordinator on 24/03/2008.

An interview held with Ato Ermias Wesenu, production supervisor of TikurAbay Leather shoe factory S.C. (D/B branch), on 20/03/2008.

An interview with Ato Fekadu Negash, President of D/B city first instance court on 24/03/2008.

An interview held with Ato Getachew, manager of D/B Blanket factory PLC, on 21/03/2008.

An interview held with Ato Getaneh Zike,facility manager of Dashen brewery s,c,on $22 / 03 / 2008$.

An interview held with W/ro Roza Seifu, quality control head of D/B natural spring water PLC, on 21/03/2008.

An interview held with Ato Samuel Weldehana, head of N.S zone EP, Land Adm \& EIA office, on 24/03/2008.

\section{Legal Instruments}

Amhara National Regional State Environmental Impact Assessment Proclamation No$181 / 2011$

Bamako Contention Ratification Proclamation No_353/2003

Basel Convention Amendment Ratification Proclamation NO_356/2003

Basel Protocol Ratification Proclamation No_357/2003. The Constitution of Federal

Democratic Republic of Ethiopia Proclamation No.1/1995 
Environmental Impact Assessment Proclamation of Federal Democratic Republic of Ethiopia Proc No 299/2002

Environmental Organ Establishment Proclamation of Federal Democratic Republic of Ethiopia Proc No 295/2002

Environmental Pollution Control Proclamation of Federal Democratic Republic of Ethiopia, Proc No.300/2002.

Institute of Biodiversity Conservation and Research Establishment/Amendment Proclamation of Federal Democratic Republic of Ethiopia Proc No 381/2004

Prevention of Industrial Pollution Regulation No159/2008

Public Health Proclamation Federal Democratic Republic of Ethiopia Proc No_200/2000

Rio Convention on Climate Changes and Bio-Diversity Convention, 1992

Solid Waste Management Proclamation of Federal Democratic Republic of Ethiopia Proc No. 513/2007

Stockholm Convention Ratification Proclamation No 192/2000 